\title{
İş Stresi ve Rol Belirsizliğinin Presenteizm (İşte Var Olamama) Üzerindeki Etkisinin Belirlenmesi ${ }^{1}$
}

\author{
DOI: 10.26466/opus.601608
}

*

\author{
Meryem Derya Yeșiltaș - Esra Ayaz ${ }^{* *}$ \\ * Dr. Öğr. Üyesi, Osmaniye Korkut Ata Üniversitesi, İ̈BF, Osmaniye / Türkiye \\ E-Posta: deryayesiltas@osmaniye.edu.tr ORCID: 0000-0001-5067-4538 \\ ** Doktora Öğrencisi, Osmaniye Korkut Ata Üniversitesi, SBE, Osmaniye / Türkiye \\ E-Posta: esraayaz92@hotmail.com \\ ORCID: $\underline{0000-0003-1641-2803}$
}

\section{Öz}

Presenteizm, çalışanların bedenen işinin başında olduğu halde, zihinsel olarak işinin başında olamaması durumudur. Presenteizm mental ve fiziksel sağllk sorunlarına sebep olabilmekte hem çalışanın hem de örgütün verimliliğini negatif yönde etkilemektedir. Bu araştırmada, iş stresi ve rol belirsizliğinin presenteizm üzerindeki etkisinin incelenmesi amaçlanmıştır. Araştırmanın örneklemi Kahramanmaraş ilinde faaliyetlerini sürdüren bir ofis mobilyası fabrikasının 128 çalışanından oluşmaktadır. Toplanan veriler açımlayıcı faktör analizi, güvenirlilik analizi, $t$ testi, ANOVA, korelasyon ve çoklu regresyon analizleri kullanılarak incelenmiştir. Sonuçlar, presenteizm ve alt boyutlarının iş stresi ve rol belirsizliği değişkenleri ile arasında pozitif yönlü anlaml ilişki olduğunu göstermektedir. İş stresi ve rol belirsizliği değiş̧kenlerinin presenteizm ve alt boyutları (psikolojik odaklı presenteizm, iş odaklı presenteizm) üzerinde pozitif yönlü etkilere sahip olduğunu ortaya koymaktadır. Ek olarak, presenteizmin cinsiyet, eğ itim düzeyi ve iş yerindeki çalışma süresine göre farklılaşması incelenmiştir. Analizler sonucunda presenteizmin üç türünde de cinsiyet ve medeni hal açısından farklılaşmadığı belirlenmiştir. Ancak, tek boyutlu presenteizm ve iş odakl presenteizm alt boyutunda eğitim seviyelerine göre anlaml farklılaşma gözlenirken, psikolojik odaklı presenteizmde gözlenmemiştir. Psikolojik odakl presenteizm alt boyutunun çalışma süresine göre farklılaştığı ama iş odaklı presenteizm alt boyutunun farklılaşmadığı görülmüştür.

Anahtar Kelimeler: Presenteizm, Rol belirsizlĭgi, İşstresi, Psikolojik odaklı presenteizm, $\dot{I}_{s}$ odaklı presenteizm

\footnotetext{
${ }^{1}$ Bu makale, 18. Uluslararası İşletmecilik Kongresinde (Mayıs, 2019) sunulmuş olan bildirinin geliştirilmesi ile hazırlanmıştır.
} 


\title{
Determination The Effect of Work Stress and Role Ambiguity on Presenteeism
}

\begin{abstract}
Presenteeism is the situation where the employees are physically at work but not mentally. Presenteeism can cause mental and physical health problems on employees and affect the efficiency of both employee and organization negatively in the long term period. In this study, it was aimed to examine the effect of work stress and role ambiguity on presenteeism. The sample of the study consists of 128 employees of an office furniture factory in Kahramanmaras. The collected data were analyzed using exploratory factor analysis, reliability analysis, $t$ test, ANOVA, correlation and multiple regression analysis. The results show that there are positive significant relationships between the dimensions of presenteeism and variables of work stress and role ambiguity. The results indicate that job stress and role ambiguity variables have positive effects on presenteeism and its subdimensions (psychological focus presenteeism, work focus presenteeism). Additionally, the differentiation of presenteeism was examined according to gender, education level and seniority in the workplace. As a result of the analysis, it was determined that all three types of presenteeism did not differ according to gender. The significant differences were observed between the education level groups in both one-dimension presenteeism and its work focus subdimension whereas significant difference was not observed in terms of psychological focus presenteeism subdimension. it was seen that psychological focus presenteeism subdimension differed according to the seniority in the workplace but work focus presenteeism subdimension did not.
\end{abstract}

Keywords: Presenteeism, Role Ambiguity, Work Stress, Psychological focus presenteeism, Work focus presenteeism 


\section{Giriş}

Çalışma hayatında çeşitli sorunlara ve büyük maliyetlere yol açan presenteizm, özellikle iş yükünün ve sorumlulukların ağır olduğu çalışanlarda ortaya çıkan, çalışanın rahatsızlanmasına rağmen işe gitmesi ve fiziksel olarak orada olmasına rağmen zihinsel olarak orda olamaması durumudur (Lowe, 2002). Presenteizm çalışanların, uzun süreli hastalık, kaygı, stres, yaralanma, depresyon, baş ve sırt ağrıları, erken emeklilik gibi iş ile alakalı zihinsel ve fiziksel rahatsızlıkların yanı sıra alkol ve uyuşturucu bağımlılığı ve iş-aile yaşamında dengesizlikler gibi sorunlara sebep olmaktadır (Hemp, 2004; Quazi, 2013).

Presenteizm, işletme açısından maliyetinin yüksek olması sebebiyle sadece çalışanların değil aynı zamanda işletmenin de temel sorunlarından biri haline gelmektedir. İş görenlerin hastayken çalışması düşük performans ve düşük verimliliğe yol açmasının yanı sıra uzun vadede ciddi mental ve fiziksel sağlık sorunlarına sebep olabilmektedir (Burton Chen, Conti, Schultz, ve Edington, 2006; Hemp, 2004; Robertson ve Cooper, 2011). Örgütlerin göstermiş oldukları yüksek performanslarının sürdürülebilir olması ve uzun vadede toplum refahının sağlanması bakımından işgücü verimliliği önemli bir faktördür. Koopman ve arkadaşları (2002) işgücü verimliliğini doğrudan (iş eğitimi ya da mesleki eğitim) ya da dolaylı (kişilerin sağlığı ve refahı gibi) olarak verimliliği etkileyen çeşitli faktörler olduğunu belirtmişlerdir. İş yükü ve sağlıksız çalışma koşullarının presenteizm ile yakın bir ilişkisi olduğu; presenteizmin yoğun iş temposu ve iş stresinin sonucu olarak ortaya çıktı̆̆ görülmektedir (Lowe, 2002, s.1). Yapılan araştırmalara bakıldığında çalışan bireyin işe gitmemesinden çok, işe gidip zihinsel olarak kendini işe verememesi durumunun işletmeler açısından daha maliyetli olduğu görülmektedir (Hemp, 2004).

$\mathrm{Bu}$ araştırmanın amacı çalışanların presenteizm algılarının incelenmesi, iş stresi ve rol belirsizliğinin presenteizmi ne şekilde etkilediğinin açılanması ve alt boyutları düzeyinde değerlendirilmesidir. Literatüre bakıldığında presenteizm kavramının, duygusal bağlılık (Erbaş, 2017), liderlik davranışları (Bölür, 2018), örgütsel bağlılık (Özmen, 2011; Baysal vd., 2014; Kaygın, Kerse, ve Yılmaz, 2017), örgütsel sinizm (Balcı, 2016), örgütsel sessizlik (Oruç, 2015), psikolojik sözleşme (Bal, 2014), stres (Gilb- 
reath ve Karimi, 2012), performans (Burton vd., 2006) gibi kavramlarla ilişkilendirildiği belirlenmiştir. Fakat bu çalışmalarda presenteizm kavramı tek boyutlu olarak ele alındığı, alt boyutlarının incelenmediği görülmek-

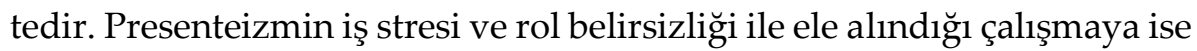
rastlanılamamıştır. Bu nedenle iş stresi ve rol belirsizliğinin presenteizmin üzerindeki etkisinin olup olmadığının hem presenteizmin tek boyutlu yapısı ile hem de alt boyutları düzeyinde incelenmesi bakımından araştırma ilgili literatüre katkı sağlayacaktır. Ulusal literatürde rol belirsizliği ile presentezim arasındaki ilişkiyi inceleyen çalışmaya rastlanamazken, yabancı yazında bu ilişkiye dair az sayıda çalışma olduğu tespit edilmiştir. Özellikle ulusal yazında bu tür bir incelemenin olmaması bu çalışmanın özgün ve değerli olmasını sağlamaktadır. Araştırmanın presenteizmin önemine yönelik farkındalığın oluşması ve önlenmesi bakımından da uygulamacılara fayda sağlaması beklenmektedir.

\section{Kuramsal Çerçeve}

\section{Presenteizm Kavramı}

Kavram İngilizce de "presence" olarak geçen kelimeden türetilmiştir. Kelimenin anlamı; var olma, hazır bulunma ve görünüş olarak ifade edilmektedir (Çiftçi, 2010). Lowe (2002); çalışanların fiziksel veya ruhsal rahatsızlıklar yaşamaları halinde işe gitmemeleri gerekirken mevcut işlerini kaybetme veya kariyerlerindeki hedeflerine ulaşamama korkusu gibi sebeplerden ötürü işe gitmeleri durumunu presenteizm kavramı ile açıklamaktadır (Bierla, Huver ve Richard, 2013). 1970'li yıllarda araştırmacılar presenteizm kavramı ile "absenteeism" kavramını aynı anlamda kullanmışlardır. Fakat 1980'lerden günümüze bu iki kavram arasındaki farklar belirgin hale gelmeye başlamıştır (Johns, 2010). Çalışanın rahatsızlanması sonucunda işe gitmemesi absenteeism, çalışanın rahatsızlanmasına rağmen işe gitmesi ve fiziksel olarak orada olması fakat zihinsel olarak orda olmaması durumu da presenteizm olarak değerlendirilmiştir. Çeşitli sebeplerden ötürü rahatsızken işe gitmeme durumu yerini rahatsızken işe gitme durumuna yani presenteizme birakmıştır (Roelen ve Groothoff, 2013; Akt. Bal, 2014). 
Koçoğlu (2007) bireylerin presenteizm ile üç sebepten dolayı karşılaştıklarını belirtmiştir. Birincisi; fiziksel ve ruhsal hastalıklar, ikincisi çalışanın sadece işini düşünmesi olarak ifade edilirken, üçüncü sebep ise fazla mesailerdir. Çalışanların, sağlıklarının bozulması, üzerlerindeki iş yükünün fazla olması, işin zor olması, profesyonellik, rahatsızlığın çok fazla önemsenmemesi, pozisyonun ya da işin kaybedilme endişesi, olumsuz sözlerden ya da davranışlardan çekinme ve işletmeye duyulan sevgi presenteizm algısını arttıran diğer faktörlerdendir (Biron vd., 2006, s.34). Aynı zamanda işletmelerdeki düzensiz ve uzun çalışma saatleri, olumsuz çalışma şartları çalışanları ve iş-yaşam dengesini negatif etkilemektedir (Deery ve Jago, 2009). Uzun çalışma saatleri çalışanın, yeteri kadar dinlenememesine, ailesine ve kendisine yeteri kadar zaman ayıramamasına, çalışmış olduğu süre içerisinde yerine getirmesi gereken diğer sorumluluklarını yapamamasına neden olurken, bu durum bireyin daha fazla stres yaşamasına ve buna bağlı olarak hem zihinsel hem de fiziksel sağlık sorunları yaşamasına sebep olabilmektedir (Arslaner ve Boylu, 2015). Çal1şanların elde etmiş oldukları kazancın, almış oldukları hastalık ödeneğinin, işletmelerin küçülme kararlarının ve istihdamın devamlılığı konusu ile ilgili örgütsel politikaların da presenteizme neden olduğu ifade edilmektedir (Johns, 2010).

Presenteizmin örgüte ve çalışanlara hem maddi hem de manevi yönden olumsuz sonuçları olmaktadır. Hata oranlarının artması, verimlilik kaybı, hizmet kalitesinin düşmesi bu sonuçlardan birkaçıdır (Gilbreath ve Karimi, 2012). Bunlarla beraber çalışanın işe odaklanamaması, yoğun stres altında kalması, diğer çalışanlarla ilişkilerinin zayıflaması gibi sorunlarla da karşılaşılmaktadır (Arslaner ve Boylu, 2015). Kendisini kötü hisseden çalışanın iş yerine geldiği için verimde ortaya çıkan kaybın maliyeti, o çalışana hastalandığı zaman ödenen tazminat, ilaç, doktor gibi masraflardan daha fazladır. Yapılan bir araştırmada genel bazı rahatsızlıklar (alerji ve baş ağrısı gibi) sebebiyle üretimde ortaya çıkan kayıp, o işletmede çalışan bütün personele harcanacak olan toplam sağlık harcamalarının \%80'inden fazla olduğu görülmüştür (Koçoğlu, 2007).

Presenteizm, iş odaklı presenteizm ve psikolojik odaklı presenteizm olmak üzere iki alt boyutta incelenebilmektedir (Koopman, 2002, s.15). İş odaklı presenteizm işkolik çalışanların presenteizm algılarını, çalışmayı 
tamamlamaya yoğunlaşılmasını; psikolojik odaklı presenteizm ise hastalıklara bağlı oluşmakta olup, işe bilişsel, duygusal ve davranışsal yoğunlaşılmasını ifade etmektedir (Koopman, 2002, s.15-19).

\section{İşStresi Kavramı}

Stres kavramı, bireyin çevresindeki potansiyel tehdit edici durumlara vermiş olduğu fiziksel ve duygusal tepkidir. İş stresi ise iş ile ilgili unsurların çalışan etkileşimi ile oluşan baskı sonucu çalışanın bilişsel ve fiziksel işleyişinde sapma meydana gelmesi olarak ifade edilmiştir (Beehr ve Newman, 1978). Günlük yaşamın her anında olduğu gibi iş ortamında da stres oldukça yoğun yaşanmaktadır. Stres altında olan çalışanların, kan şekerinin yükselmesi, iştah bozukluğu, baş dönmesi, ağız kuruması, anksiyete ve depresyon gibi psikolojik, fizyolojik ve davranışsal tepkiler gösterdiği ortaya koyulmuştur (Selye,1976; Akt. Kara ve Sezici, 2013). İş yerindeki stresin devamsızlık oranlarının fazlalaşmasına, kazalara ve yaralanmalara neden olması sebebiyle yalnızca çalışanları değil aynı zamanda örgütün işleyişini de olumsuz etkileyebilmesi mümkündür (Çelik ve Turunç, 2009).

Çalışanların kişilikleri haricinde yaptıkları işten ve çalıştıkları örgütten kaynaklanan bazı faktörler stres düzeylerini etkilemektedir. Çalışma şartları, örgütün politikaları, örgüt yapısı, iş yapma süreçleri çalışılan örgütten ve işten kaynaklı stres yapıcılardır. İş çevresinin çalışan üzerinde yaratmış olduğu baskı ile çalışanın kapasitesi arasındaki uyumsuzluk iş stresinin oluşmasına sebep olabilmektedir (Efeoğlu ve Özgen, 2007). Çalışanın iş dışından getirdiği maddi sıkıntılar, aile sorunları gibi faktörler de iş stresi üzerinde etkili olmaktadır (Schafer, 1987; Akt. Turunç ve Çelik, 2010).

\section{Rol Belirsizliği Kavramı}

Rol kavramı, bir birey veya bir gruptan beklenilen çeşitli davranışları ifade etmektedir. Çalışanların özel ve iş hayatlarında yerine getirmeleri beklenilen birtakım davranışlar bulunmaktadır. Bu davranışlar, roller olarak ifade edilmekte olup, kapsamları çeşitli normlar ile önceden belirlen- 
miştir. Çalışanların gerek özel hayatlarında gerekse iş hayatlarında kendilerine yüklenen rollere ilşkin davranışları ve görevleri yerine getirmeleri beklenmektedir (Şimşek, Akgemci ve Şerif, 2010).

Rol belirsizliği kavramını Sager (1994), çalışanın rolünü yerine getirmek amacıyla ihtiyaç duyduğu yeterli bilgiden yoksun olması ve üstlerinin kendisinden ne istediklerini tam anlamıla bilememesi durumu olarak tanımlarken, Peterson ve arkadaşları (1995) bir rolün gerekliliklerini yerine getirmek amacıyla hangi faaliyetlerde bulunulması gerektiği konusunda yaşanan belirsizlik hali olarak tanımlamıştır (Basım, Erkenekli, ve Şeşen, 2010).

\section{Presenteizm, İş Stresi ve Rol Belirsizliği ìlişkisi}

Birçok kuruluş karşı karşıya kaldığı küresel rekabette üretken işgücü ile rekabet avantajı kazanmaktadır. Presenteizm ise çalışanın persformansını ve uzun vadede kurumun verimliliğini ve devamlılı̆̆ını olumsuz yönde etkilemektedir. Araştırmalarda presenteizmin genellikle stresin sonucunda ortaya çıtığı görülmektedir (Cooper, 1998; Koçoğlu, 2007; Macgregor, Cunningham ve Caverley, 2008; Chia ve Chu, 2016). Bir çalışmada, zaman baskısı, iş güvencesizliği, iş yükü ve kariyer imkânlarının azlığının çalışanları strese soktuğunu böylece presenteizme sebep olduğu ifade edilmiştir (Hansen ve Andersen, 2008). Bir diğer çalışmada ise, engelleyici stresin, presenteizm ile pozitif ilişkili olduğu belirlenmiştir (Yang vd, 2017)

Yapılan araştırmalar rol belirsizliğinin çalışanlar açısından sonuçlarının belirsizlik, azalan iş tatmini, yüksek endişe düzeyleri ve iş stresi olduğunu ifade etmektedir (Getzels ve Guba, 1954; Kahn et al., 1964; Kelloway ve Barling, 1990; Quah ve Campbell, 1994). Rol belirsizliği ile presenteizm arasındaki ilişkiyi test eden sadece bir çalışmaya rastlanılmış olup, araştırma sonucunda rol belirsizliğinin presenteizmle ilişkili üretkenlik arasinda negatif yönlü korelasyon olduğu görülmüştür (Zhou, Martinez, Ferreira, ve Rodrigues, 2016). Webster ve arkadaşları (2011) ise çalışmalarında, zorlayıcı stres ile rol belirsizliği, rol çatışması ve iş yükü arasında pozitif yönlü korelasyon olduğu sonucuna ulaşmışlardır.

Rol belirsizliği yaşayanlar özel ve iş hayatları arasında denge kuramayarak yoğun stres altına girmektedirler. Bu durum da çalışanların hem iş 
hayatlarında hem de özel hayatlarında mutlu olmalarını engelleyerek presenteizm yaşamalarına sebep olabilmektedir (Biron vd., 2006). Kendisinden tam olarak ne beklenildiğini anlayamayan çalışanlar, yapmış oldukları işten emin olmadan çalışmakta, psikolojik anlamda kendilerini güvende hissetmemektedir (Anık, Baysal, Aksu, Aksu, 2014). Rol belirsizliği yaşayan çalışanların görevini etkili bir biçimde yapılamaması kendilerine güvensizlik duymalarına, düşük iş tatminine ve presenteizme neden olmaktadır (Eroğlu, 2007). Yaşanılan psikolojik problemler sonucunda çalışanların iş yaşamları da etkilenmektedir. Rol belirsizliği, çalışanların tükenmişlik, depresyon gibi problemler yaşamasına ve bu durum da presenteizmin oluşmasına neden olmaktadır. Presenteizm sonucunda ise verim ve performans düşüklüğü görülmektedir (Erbaş, 2017).

\section{Araştırma Soruları}

İş hayatında gün geçtikçe artan sorunlara ve büyük maliyetlere yol açan presenteizm, ağır iş yüküne ve sorumluluğa sahip çalışanlarda ortaya ç1kan rahatsızlıklar sebebiyle daha sık görülmekte olup, yoğun stres faktörünün olduğu işletmelerde daha sık yaşanmaktadır (Koçoğlu, 2007). Stres, çalışanları doğrudan etkilerken, onların davranışlarını, verimliliklerini ve diğer çalışanlarla olan ilişkilerini de belirlemektedir. Rol belirsizliği ve iş stresine maruz kalmanın fiziksel ve ruhsal rahatsızlıklar, kendini işe verememe, özgüven eksikliği, iş doyumsuzluğu, kararların niteliğinde ve yaratıcılıkta azalma gibi olumsuz sonuçlarının olduğu belirlenmiştir (Bartram vd., 2004). Nitekim rol belirsizliği ve yoğun stres yaşayan çalışanların iş görememezlik oranlarının daha yüksek olduğu görülmüştür. Çalışanların ruhsal veya bedensel bakımdan rahatsız olduklarında aralıklarla da olsa çalışamaz duruma gelmeleri, bu bakımdan işe gitmek istememelerine sebep olabilmektedir. İşe gitme zorunluluğundan dolayı işe giden çalışan, düşük performansla ve hatalı çalışacağı için genel anlamda verimin düşmesine sebep olmaktadır. Presenteizm sorunu da bu durumda ortaya çımaktadır (Yeşiltaş ve Erbaş, 2017).

$\mathrm{Bu}$ araştırmanın amacl, çalışanların hem örgüt hem de çalışan verimliliği ve sürekliliği açısından önem taşıyan presenteizm algılarının incelen- 
mesi, iş stresi ve rol belirsizliğinin presenteizm üzerindeki etkisinin açıklanmasıdır. Bu amaçla aşağıdaki araştırma soruları geliştirilerek analizler gerçekleştirilmiştir.

- Çalışanların presenteizm algıları demografik değiş̧kenlere göre farklılaşmakta midır?

- Çalışanların rol belirsizliği ve iş stresi ile presenteizmi algılamaları arasında ilişki var mıdır?

- Rol belirsizliği ve iş stresinin presenteizm üzerindeki etkisi nedir?

\section{Yöntem}

\section{Evren ve Örneklem}

Araştırmanın evrenini Kahraman Maraş organize sanayinde faaliyet gösteren yoğun iş stresi yaşayan mavi ve beyaz yaka çalışanlar oluşturmaktadır. Araştırmanın evrenini temsilen örneklem olarak Kahramanmaraş'ta ofis mobilyası üretimi yapan bir fabrikadaki 15 beyaz ve 113 mavi yakalı çalışandan veri toplanmıştır. Çalışma ortamlarında birden fazla görevi aynı anda yerine getirmek zorunda kalmaları, çalışma sürelerinin değişken olması, zaman ve sipariş yetiştirme baskısı altında çalışmaları sebebiyle ofis mobilyası fabrikası çalışanları seçilmiştir. Kolayda örneklem yöntemi kullanılmış olup, anketler 133 çalışana dağıtılmış, süreç sonunda 2 geçersiz, 128 geçerli toplamda 130 anket geri dönmüştür. Anket dönüş oranı $\% 97,74^{\prime}$ tür.

Örneklem sayısı belirlenirken genel kural analiz edilecek ifade sayıs1nın en az 5 katı ve üstü olmasıdır (Hair, Anderson, Tatham ve Balck, 1995, s.373). Presenteism ölçeği 6 ifade, rol belirsizliği 6 ifade ve iş stresi 7 ifade olmak üzere çalışmanın anketi 19 ifadeden oluşmaktadır. Bu durumda örneklemin en az 95 katılımcıdan oluşması gerekmektedir. Örneklem sayısı 128 olup, söz konusu kuralı sağlamaktadır.

\section{Veri Toplama Araçlan}

Anket formu dört bölümden oluşmaktadır. İlk bölümde presenteizm ölçeği, ikinci bölümde katılımcıların rol belirsizliğine yönelik ölçek, üçüncü 
bölümde katılımcıların iş stresine yönelik ölçek, son bölümde ise katılımcıların demografik özelliklerine ilişkin sorular yer almaktadır. Araştırmada, Koopman ve arkadaşları (2002) tarafından geliştirilen, iş odaklı presenteizm ( 3 madde) ve psikolojik odaklı presenteizm (3 madde) olmak üzere iki alt boyut ve 6 sorudan oluşan "Stanford Presenteeism Ölçeği" kullanılmıştır. Türkçe versiyonu Oruç (2015)'un çalışmasından alınmıştır. Presenteizm ölçeği alan yazında 6 ifade tek boyut olarak değerlendirilebileceği gibi, Koopman vd. (2002, s.15)'nin çalışmasında ifade edildiği şekilde iki boyutlu olarak da kullanmak mümkündür. Bu çalışma kapsamında presenteizm her iki şekilde de ele alınarak incelenmiştir.

Çalışmada yer alan diğer değişken olan rol belirsizliğinin ölçümü için Rizzo vd. (1970) tarafından geliştirilen rol çatışması ve rol belirsizliği ölçeğindeki rol belirsizliğini ölçmek için kullanılan 6 ifadeden yararlanılmıştır. Çalışmadaki diğer değişken ise iş stresidir. İş stresi değişkeninin ölçümünde ise House ve Rizzo (1972) tarafından geliştirilmiş, 7 ifadeden oluşan iş stresi ölçeği kullanılmıştır. Bu ölçek çalışanın iş ortamında yaşamiş olduğu stresin hangi düzeyde zihnini meşgul ettiğini belirlemeye yönelik olarak düzenlenmiştir. Üç ölçekte 5'li Likert ifadeleri kullanılmıştır.

\section{Faktör ve Güvenilirlik Analizleri}

Yapılan analizlerin örneklem uygunluklarını ve ölçeklerin faktör yapılarını test etmek amacı ile açımlayıcı faktör analizi yapılmıştır. Presenteizm ölçeğinde Quartimax yönteminden yararlanılırken diğer iki ölçek için döndürme yöntemi kullanılmamıştır. Presenteizm ölçeğine ait Kaiser-Meyer-Olkin (KMO) Örneklem Uygunluğu Testi sonucu ise ,68 olarak elde edilmiş ve Bartlett'in Küresellik Testi de anlamlı olarak bulunmuştur $\left(\chi^{2}=\right.$ $312,741 ; \mathrm{p}<0,01)$. Faktör analizi sonucunda presenteizm ölçeğinde, toplam varyansın \%74,274'ünü açıklayan iki faktör elde edilmiş olup, bunlar iş odaklı presenteizm (3 ifade; Cronbach Alpha: ,85), psikolojik odaklı presenteizm (3 ifade; Cronbach Alpha: ,77) boyutları olmuştur.

Rol belirsizliği ölçeğine ait Kaiser-Meyer-Olkin (KMO) Örneklem Uygunluğu Testi sonucu 0,80 olarak elde edilmiş ve Bartlett'in Küresellik Testi de anlamlı olarak bulunmuştur $\left(\chi^{2}=278,462 ; p<0,01\right)$. İş stresi ölçeğine ait Kaiser-Meyer-Olkin (KMO) Örneklem Uygunluğu Testi sonucu 
,84 olarak elde edilmiş ve Bartlett'in Küresellik Testi de anlamlı olarak bulunmuştur $\left(\chi^{2}=277,185 ; p<0,01\right)$. İş stresi ölçeği toplam varyansın $\% 49,47$ 'ini açılayan tek boyutta; rol belirsizliği de toplam varyansın $\% 53,331$ 'ini açıklayan tek boyutta toplanmıştır.

Tablo 1: Kullanılan Ölçeklere İlişkin KMO ve Güvenilirlik Değerleri

\begin{tabular}{lllll}
\hline & Soru sayısı & KMO & $\begin{array}{l}\text { Açıklanan } \\
\text { Varyans \% }\end{array}$ & $\begin{array}{l}\text { Cronbach } \\
\text { Alpha }\end{array}$ \\
\hline Presenteizm & 6 & & 74,274 &, 733 \\
Psikolojik odaklı presenteizm & 3 & & 69,318 &, 778 \\
İş odaklı presenteizm & 3 &, 683 & 78,193 &, 859 \\
Rol belirsizliği & 6 &, 801 & 53,331 &, 813 \\
İşs stresi & 7 &, 843 & 49,471 &, 826 \\
\hline
\end{tabular}

Yapılan araştırmada kullanılan ölçeklerin güvenilirliğini test etmek amacıyla Alfa $(\alpha)$ Modeli kullanılmıştır. Buna göre Cronbach Alfa değerleri; iş odaklı presenteizm için , 85 psikolojik odaklı presenteizm için ,77 rol belirsizliği için , 81 ve iş stresi için , 82 olarak bulunmuştur. Daha önce yapılan çalışmalarda Cronbach Alfa değerleri; presenteizm için ,76 (Balc1,2016, s.153); ,86 (Okcu, 2017, s.24); ,72 (Ağırbaş,2018, s. 57) iş odaklı presenteizm için; ,77 (Bakan vd., 2018, s. 380) psikolojik odaklı presenteizm için; ,75 (Bakan vd., 2018, s.380) rol belirsizliği için; ,79 (Tunç, 2008, s. 94); ,56 (Akdaş, 2015, s.52); ,85 (Ceylan ve Ulutürk, 2006, s.52) iş stresi için ise; ,81 (Yeşiltaş ve Türk, 2017, s. 938); ,75 (Yurdadön, 2018, s. 53); ,85 (Turunç ve Çelik, 2010, s.194) olarak bildirilmiştir. Bu veriler ışığında araştırmadaki değişkenlerin güvenilirlik değerlerinin yüksek olduğu ve anketlerin katılımcılar tarafından uygun şekilde doldurulduğu kabul edilmektedir.

\section{Bulgular}

Bu bölümde katılımcıların demografik özelliklerine ve araştırma sorularına yönelik bulgulara yer verilmiştir. 


\section{Katılımcıların Demografik Özellikleri}

Katılımcıların demografik özelliklerine bakıldığında, \%59,4'ünün evli, \%40,6'sının bekâr, \%87,5'inin erkek, \%12,5'unun ise kadın olduğu görülmektedir. Tablo 2'de katılımcıların çalışma sürelerine bakıldığında \%10,9'u 1 yıldan az, \%43'ü 1-5 yıl, \%29,7'si 6-10 yıl, \%8,6'sı 11-15 yıl, \%7,8'i ise 16 yıl ve üzeri cevabını verdikleri görülmektedir.

Tablo 2: Katılımcıların Demografik Özelliklerinin Frekans Dağılımları

\begin{tabular}{lllllllll}
\hline Eğitim & Sayı & \% & Yaş & Sayı & \% & $\begin{array}{l}\text { Çalışma } \\
\text { Süresi }\end{array}$ & Sayı & $\%$ \\
\hline İlkokul & 17 & 13,3 & $\mathbf{2 5}$ ve Altı & 12 & 9,4 & $\begin{array}{l}\mathbf{1} \\
\text { Yıldan Az }\end{array}$ & 14 & 10,9 \\
\hline Ortaokul & 63 & 49,2 & $\mathbf{2 6 - 3 0}$ & 50 & 39,1 & $\mathbf{1 - 5}$ Yıl & 55 & 43,0 \\
\hline Lise & 36 & 28,1 & $\mathbf{3 1 - 3 5}$ & 31 & 24,2 & $\mathbf{6 - 1 0}$ Yıl & 38 & 29,7 \\
\hline Yüksekokul & 6 & 4,7 & $\mathbf{3 6 - 4 0}$ & 23 & 18,0 & $\mathbf{1 1 - 1 5}$ Yıl & 11 & 8,6 \\
\hline Lisans & 6 & 4,7 & $\mathbf{4 1}$ ve Üzeri & $\mathbf{1 2}$ & 9,4 & $\mathbf{1 6}$ ve Üzeri & 10 & 7,8 \\
\hline
\end{tabular}

Katılımcıların yaşlarına göre dağılımına bakıldığında, \%39,1'inin 2630, \%24,2'sinin 31-35 yaş, \%18'inin 36-40 yaş, \%9,4'ünün 40 yaş ve üzerinde olduğu, \%9,4'ünün ise 25 yaşında veya daha küçük yaşta olduğu ortaya çıkmıştır. Araştırmaya katılan katılımcların eğitim durumuna bakıldığında, \%62,5'inin ilkokul ve ortaokul, \%28,1'inin lise, \%9,4'ünün ise yüksekokul ve lisans mezunu olduğu görülmektedir.

\section{Araştırma Sorularına İlişkin Bulgular}

- Araştırma Sorusu 1: Çalışanların presenteizm algıları demografik değişkenlere göre farklılık göstermekte midir?

Çalışanların presenteizm ve boyutlarına yönelik algılarının incelenmesi amacıyla yaş, cinsiyet ve çalışma süresi bakımından farklılaşmaları test edilmiştir. Çalışanların presenteizm algılarının cinsiyete göre farklılaşmasının incelenmesi için bağımsız örneklem t testi kullanılmıştır. Presenteizm, iş odaklı presenteizm ve psikolojik odaklı presenteizm boyutlarının cinsiyete göre farklılaşmasına ilişkin bağımsız örneklem $t$ testi so- 
nuçları Tablo 3'de verilmiştir. Analiz sonucunda üç değişkenin de cinsiyete göre farklılaşmadığı, presenteizm algısının ortalamalarının birbirine yakın olduğu belirlenmiştir.

Tablo 3: Katılımcıların Presenteizm Algılarının Cinsiyete Göre Farklılaşması Bağımsız Örneklem $t$ Testi

\begin{tabular}{|c|c|c|c|c|c|c|c|c|c|c|}
\hline \multirow{2}{*}{\multicolumn{2}{|c|}{ Cinsiyet $\mathbf{N}$}} & \multirow[b]{2}{*}{ Ort. } & \multicolumn{2}{|c|}{$\begin{array}{c}\text { İş Odaklı } \\
\text { Presenteizm }\end{array}$} & \multicolumn{3}{|c|}{$\begin{array}{c}\text { Psikolojik Odaklı } \\
\text { Presenteizm }\end{array}$} & \multicolumn{3}{|c|}{ Presenteizm } \\
\hline & & & $\begin{array}{l}\text { Std. } \\
\text { Sap. }\end{array}$ & $\begin{array}{l}P \\
\text { (2 tailed) }\end{array}$ & , Ort. & $\begin{array}{l}\text { Std. } \\
\text { Sap. }\end{array}$ & $\begin{array}{l}P( \\
2 \text { tailed })\end{array}$ & Ort. & $\begin{array}{l}\text { Std. } \\
\text { Sap. }\end{array}$ & $\begin{array}{l}P(2 \text { ta- } \\
\text { iled) }\end{array}$ \\
\hline Kadın & 16 & 2,6458 & 1,22607 & \multirow{3}{*}{0,160} & 2,7083 & ,76860 & \multirow{3}{*}{0,341} & 2,6771 & 87023 & \multirow{3}{*}{0,580} \\
\hline Erkek & 112 & 2,1756 & 1,00146 & & 2,9196 & 1,08428 & & 2,5476 & 79015 & \\
\hline Durum & 128 & $\mathrm{P}>0,05$ & & & $P>0,05$ & & & $P>0,05$ & & \\
\hline
\end{tabular}

Çalışanların presenteizm algılarının sahip oldukları eğitime göre farklılaşmasını incelemek amacıyla Tek yönlü ANOVA analizi yapılmıştır.

Tablo 5: Çalışanların Presenteizm Algılarının Ĕ̆itim Düzeylerine Göre Farklılaşması ANOVA Tablosu

\begin{tabular}{lllllll}
\hline & & $\begin{array}{l}\text { Karelerin } \\
\text { Toplamı }\end{array}$ & df & $\begin{array}{l}\text { Karelerin } \\
\text { Ortalaması }\end{array}$ & F & $\begin{array}{l}\text { Anlam } \\
\text { Düzeyi }\end{array}$ \\
\hline \multirow{2}{*}{$\begin{array}{l}\text { Is S Odaklı } \\
\text { Presenteizm }\end{array}$} & Gruplar arası & 12,247 & 3 & 4,082 & 4,059 &, 009 \\
& $\begin{array}{l}\text { Grup içi } \\
\text { Toplam }\end{array}$ & 124,722 & 124 & 1,006 & & \\
\hline \multirow{2}{*}{$\begin{array}{l}\text { Psikolojik } \\
\text { Odaklı }\end{array}$} & Gruplar arası & 5,723 & 3 & 1,908 & 1,762 &, 158 \\
Presenteizm & Toplam & 134,262 & 124 & 1,083 & & \\
\hline \multirow{2}{*}{ Presenteizm } & 139,985 & 127 & & & \\
& Gruplar arası & 6,431 & 3 & 2,144 & 3,570 &, 016 \\
& Grup içi & 74,465 & 124 &, 601 & & \\
\hline
\end{tabular}

Yapılan analiz sonucunda psikolojik odaklı presenteizm boyutu $(p=0,158>0,05)$ değerleri açısından eğitim düzeyi grupları arasında anlamlı bir fark görülmemiştir. Presenteizm boyutlarından iş odaklı presenteizm boyutu $(\mathrm{p}=0,009<0,05)$ ve presenteizm tek boyutlu değerlendirildiği durumda $(p=0,016<0,05)$ çalışanların eğitim düzeyleri arasında anlamlı bir farklılık belirlenmiş olup, lisans ve yüksekokul eğitimine sahip çalışanların presenteizmi diğer eğitim gruplarındaki çalışanlardan daha farklı algıladıkları belirlenmiştir. 
Tablo 6: Çalışanların Presenteizm Algılarının Ĕ̆itim Düzeylerine Göre Farklılaşması ANOVA Post Hoc Karşılaştırmalar Tablosu

\begin{tabular}{|c|c|c|c|c|c|c|c|}
\hline \multirow{2}{*}{\multicolumn{2}{|c|}{$\begin{array}{l}\text { Tukey HSD } \\
\text { (I)Eğitim } \\
\text { Düzeyleri }\end{array}$}} & \multirow{2}{*}{$\begin{array}{l}\text { (J) Eğiti } \\
\text { Düzeyleri }\end{array}$} & \multirow{2}{*}{$\begin{array}{l}\text { Ortalamalar } \\
\text { Farkı (I-J) }\end{array}$} & \multirow{2}{*}{$\begin{array}{l}\text { Std. } \\
\text { Hata }\end{array}$} & \multirow[b]{2}{*}{$\mathbf{p}$} & \multicolumn{2}{|c|}{ \%95 Güven Aralığı } \\
\hline & & & & & & Alt Sinir & Üst Sınır \\
\hline \multirow{10}{*}{ 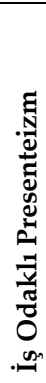 } & \multirow{3}{*}{ 1-ílkokul } & 2-Ortaokul &,- 03424 & 27410 & ,999 &,-7481 & 6796 \\
\hline & & 3-Lise &,- 05937 & 29514 & ,997 &,- 8280 & ,7092 \\
\hline & & 4-Lisans & $-1,09641^{*}$ & ,37813 & ,023 & $-2,0811$ &,- 1117 \\
\hline & \multirow{3}{*}{ 2-Ortaokul } & 1-İlkokul & , 03424 & 27410 & ,999 & -6796 & 7481 \\
\hline & & 3-Lise &,- 02513 & 20954 & ,999 &,- 5708 & ,5205 \\
\hline & & 4-Lisans & $-1,06217^{*}$ & ,31589 & ,006 & $-1,8848$ &,- 2395 \\
\hline & \multirow{3}{*}{ 3-Lise } & 1-İlkokul & ,05937 & 29514 & ,997 & -,7092 & 8280 \\
\hline & & 2-Ortaokul & ,02513 & 20954 & ,999 &,- 5205 & ,5708 \\
\hline & & 4-Lisans & $-1,03704^{*}$ & ,33430 &, 013 & $-1,9076$ &,- 1664 \\
\hline \multirow{3}{*}{\multicolumn{2}{|c|}{ 4-Lisans }} & 1-İlkokul & $1,09641^{*}$ & 37813 & ,023 & 1117 & 2,0811 \\
\hline & & 2-Ortaokul & $1,06217^{*}$ & ,31589 & ,006 & ,2395 & 1,8848 \\
\hline & & 3-Lise & $1,03704^{*}$ & ,33430 & ,013 & ,1664 & 1,9076 \\
\hline \multirow{12}{*}{ 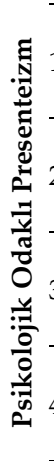 } & \multirow{3}{*}{ 1-İlkokul } & 2-Ortaokul &,- 05882 & 28439 & ,997 &,- 7994 & 6818 \\
\hline & & 3-Lise & 36710 & 30622 - r r & 629 &,- 4303 & 1,1646 \\
\hline & & 4-Lisans &,- 28105 & 39233 & ,890 & $-1,3028$ & ,7407 \\
\hline & \multirow{3}{*}{ 2-Ortaokul } & 1-İlkokul & ,05882 & 28439 & ,997 & -6818 & ,7994 \\
\hline & & 3-Lise & 36710 & 21740 & 209 & -,1402 & ,9921 \\
\hline & & 4-Lisans &,- 28105 & ,32774 & ,905 & $-1,0757$ & ,6313 \\
\hline & \multirow{3}{*}{ 3-Lise } & 1-İlkokul &,- 36710 & 30622 & 629 & $-1,1646$ & ,4303 \\
\hline & & 2-Ortaokul &,- 42593 & 21740 & 209 &,- 9921 & 1402 \\
\hline & & 4-Lisans &,- 64815 & 34685 & ,247 & $-1,5514$ & ,2551 \\
\hline & \multirow{3}{*}{ 4-Lisans } & 1-İlkokul & 28105 & 39233 & ,890 &,- 7407 & 1,3028 \\
\hline & & 2-Ortaokul & 22222 & 32774 & 905 & -6313 & 1,0757 \\
\hline & & 3-Lise & ,64815 & ,34685 & ,247 &,- 2551 & 1,5514 \\
\hline \multirow{3}{*}{\multicolumn{2}{|c|}{ 1-İlkokul }} & 2-Ortaokul &,- 04653 & 21179 & ,996 &,- 5981 & ,5050 \\
\hline & & 3-Lise & 15387 & 22805 & ,90 &,- 4400 & 7478 \\
\hline & & 4-Lisans & -68873 & ,29218 & ,091 & $-1,4496$ & ,0722 \\
\hline \multirow{9}{*}{ 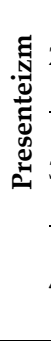 } & \multirow{3}{*}{ 2-Ortaokul } & 1-İlkokul & ,04653 & 21179 & ,996 &,- 5050 & ,5981 \\
\hline & & 3-Lise & 20040 & 16191, & 604 & ,-2212 & 6220 \\
\hline & & 4-Lisans &,$- 64220^{*}$ & 24408 & ,008 & $-1,2778$ &,- 0066 \\
\hline & \multirow{3}{*}{ 3-Lise } & 1-İlkokul & -,15387 & 22805 & 906 & $\begin{array}{l}-7478 \\
\end{array}$ & 4400 \\
\hline & & 2-Ortaokul &,- 20040 & 16191, & 604 &,- 6220 & ,2212 \\
\hline & & 4-Lisans &,$- 84259^{*}$ & ,25831 & ,008 & $-1,5153$ &,- 1699 \\
\hline & \multirow{3}{*}{ 4-Lisans } & 1-İlkokul & 68873 & 29218 & ,091 &,- 0722 & 1,4496 \\
\hline & & 2-Ortaokul & ,61220* & 24408 & ,047 & ,0066 & 1,2778 \\
\hline & & 3-Lise & ,84259* & 25831 & ,008 & 1699 & 1,5153 \\
\hline
\end{tabular}

Sonuç olarak, Tukey HSD testi kullanılarak yapılan post hoc karşılaştırmasında ortalama ve standart sapma değerleri ve önem düzeyleri göz 
önünde bulundurulduğunda, lisans eğitim düzeyine sahip çalışanlarda presenteizm ve iş odaklı presenteizm algılarının farklılaştı̆̆ı, ancak psikolojik odaklı presenteizm algılarının farklılaşmadığı belirlenmiştir. Lisans/yüksekokul eğitimine sahip çalışanların presenteizm ve iş odaklı presenteizm algılarının diğer gruplardan daha yüksek olduğu görülmektedir.

Çalışanların presenteizm algılarının firmada çalışma sürelerine göre farklılaşmasını incelemek amacıyla Tek yönlü ANOVA analizi yapılmıştir.

Tablo 7: Çalışanların Presenteizm Algılarının Firmada Çalıştıkları Süreye Göre Farklılaşması ANOVA Tablosu

\begin{tabular}{|c|c|c|c|c|c|c|}
\hline & & $\begin{array}{l}\text { Karelerin } \\
\text { Toplamı }\end{array}$ & df & $\begin{array}{l}\text { Karelerin } \\
\text { Ortalamas1 }\end{array}$ & $\mathbf{F}$ & $\begin{array}{l}\text { Anlam } \\
\text { Düzeyi }\end{array}$ \\
\hline \multirow{3}{*}{$\begin{array}{l}\text { İş Odaklı } \\
\text { Presenteizm }\end{array}$} & Gruplar arası & 4,742 & 3 & 1,581 & 1,482 & 223 \\
\hline & Grup içi & 132,227 & 124 & 1,066 & & \\
\hline & Toplam & 136,969 & 127 & & & \\
\hline \multirow{3}{*}{$\begin{array}{l}\text { Psikolojik Odaklı } \\
\text { Presenteizm }\end{array}$} & Gruplar aras1 & 11,656 & 3 & 3,885 & 3,754 & ,013 \\
\hline & Grup içi & 128,329 & 124 & 1,035 & & \\
\hline & Toplam & 139,985 & 127 & & & \\
\hline \multirow{3}{*}{ Presenteizm } & Gruplar arası & 7,452 & 3 & 2,484 & 4,194 & ,007 \\
\hline & Grup içi & 73,444 & 124 &, 592 & & \\
\hline & Toplam & 80,896 & 127 & & & \\
\hline
\end{tabular}

Yapılan analiz sonucunda, presenteizm $(\mathrm{p}=0,007<0,05)$ ve alt boyutu olan psikolojik odaklı presenteizm algılarının $(\mathrm{p}=0,013<0,05)$ iş yerinde çalışma süresine göre farklılaştığı, ancak iş odaklı presenteizm algılarının $(\mathrm{p}=0,223>0,05)$ farklılaşmadığ görülmektedir. 
Tablo 8: Çalışanların Presenteizm Algılarının Firmada Çalıştıkları Süreye Göre Farklılaşması ANOVA Post Hoc Karşılaştırmalar Tablosu Tukey HSD

\begin{tabular}{|c|c|c|c|c|c|c|c|}
\hline & \multirow{2}{*}{$\begin{array}{l}\text { (I)Çalışma } \\
\text { Süresi }\end{array}$} & \multirow{2}{*}{$\begin{array}{l}\text { (J)Çalışma } \\
\text { Süresi }\end{array}$} & \multirow{2}{*}{$\begin{array}{l}\text { Ortalamalar } \\
\text { Farkı (I-J) }\end{array}$} & \multirow{2}{*}{ Std. Hata } & \multirow{2}{*}{$\mathbf{P}$} & \multicolumn{2}{|c|}{ \%95 Güven Aralığı } \\
\hline & & & & & & Alt Sinir & Üst Sinır \\
\hline \multirow{12}{*}{ 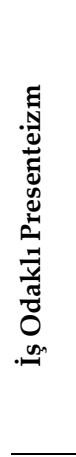 } & \multirow{3}{*}{$\begin{array}{l}1 \text { Yildan } \\
\mathrm{Az}\end{array}$} & 1-5 Y 11 & ,48182 & ,30912 & ,406 &,- 3232 & 1,2868 \\
\hline & & 6-10 Y 11 & 14912 & ,32285 & 967 &,- 6916 & ,9899 \\
\hline & & 11-15 Y1l & , 08730 & ,35629 & ,995 &,- 8406 & 1,0152 \\
\hline & \multirow{3}{*}{ 1-5 Yil } & 1 Yildan Az &,- 48182 & 30912 & ,406 & $-1,2868$ & ,3232 \\
\hline & & 6-10 Y 11 &,- 33270 & ,21783 & ,424 &,- 9000 & ,2346 \\
\hline & & 11-15 Y1l &,- 39452 & ,26489 & ,447 & $-1,0843$ & ,2953 \\
\hline & \multirow{3}{*}{ 6-10 Yil } & 1 Ylldan Az & -14912 & ,32285 & ,967 &,- 9899 & 6916 \\
\hline & & 1-5 Yll & ,33270 & 21783 & ,424 &,- 2346 & ,9000 \\
\hline & & $11-15 Y_{1} 1$ &,- 06182 & ,28078 & ,996 &,- 7930 & 6694 \\
\hline & \multirow{3}{*}{ 11-15 Y1l } & 1 Yildan Az &,- 08730 & 35629 & ,995 & $-1,0152$ & ,8406 \\
\hline & & 1-5 Yil & 39452 & 26489 & 447 & -2953 & 1,0843 \\
\hline & & 6-10 Y 11 & ,06182 & ,28078 & ,996 &,- 6694 & ,7930 \\
\hline \multirow{12}{*}{ 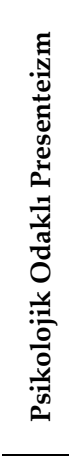 } & \multirow{3}{*}{$\begin{array}{l}1 \text { Yildan } \\
\mathrm{Az}\end{array}$} & 1-5 Yil & ,38874 & ,30453 & ,580 &,- 4043 & 1,1818 \\
\hline & & 6-10 Y1l & -16165 & 31805 & ,957 &,- 9899 & ,6666 \\
\hline & & 11-15 Y1l &,- 36508 & ,35100 & ,726 & $-1,2792$ & ,5490 \\
\hline & \multirow{3}{*}{ 1-5 Yil } & 1 Yildan Az &,- 38874 & ,30453 & ,580 & $-1,1818$ & 4043 \\
\hline & & 6-10 Y1l &,- 55040 & 21460 & ,055 & $-1,1093$ & ,0085 \\
\hline & & $11-15 Y_{11}$ &,$- 75382^{*}$ & 26096 & ,023 & $-1,4334$ &,- 0742 \\
\hline & \multirow{3}{*}{ 6-10 Y1l } & 1 Yıldan Az & 16165 & 31805 & ,957 &,- 6666 & ,9899 \\
\hline & & 1-5 Yil &, 55040 & 21460 & ,055 &,- 0085 & 1,1093 \\
\hline & & $11-15 Y_{11}$ &,- 20343 & ,27662 & ,883 &,- 9238 &, 5169 \\
\hline & \multirow{3}{*}{ 11-15 Yil } & 1 Yildan Az & 36508 & 35100 & ,726 &,- 5490 & 1,2792 \\
\hline & & 1-5 Yil & ,75382* & 26096 & ,023 & ,0742 & 1,4334 \\
\hline & & 6-10 Y 11 & ,20343 & ,27662 & ,883 &,- 5169 & ,9238 \\
\hline \multirow{12}{*}{ 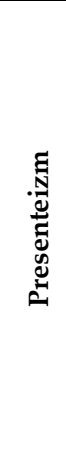 } & \multirow{3}{*}{$\begin{array}{l}1 \text { Yildan } \\
\mathrm{Az}\end{array}$} & 1-5 Yil & ,43528 & 23038 & 238 &,- 1647 & 1,0352 \\
\hline & & 6-10 Y 11 & -,00627 & 24061 & 1,000 &,- 6329 & 6203 \\
\hline & & $11-15 Y_{11}$ &,- 13889 & ,26554 & ,953 &,- 8304 &, 5526 \\
\hline & \multirow{3}{*}{ 1-5 Yil } & 1 Yıldan Az &,- 43528 & 23038 & ,238 & $-1,0352$ & 1647 \\
\hline & & 6-10 Yll &,$- 44155^{*}$ & 16234 & ,037 &,- 8643 &,- 0188 \\
\hline & & 11-15 Yil &,$- 57417^{*}$ & 19742 & , 022 & $-1,0883$ &,- 0601 \\
\hline & \multirow{3}{*}{ 6-10 Yil } & 1 Yıldan Az & ,00627 & 24061 & 1,000 &,- 6203 & 6329 \\
\hline & & 1-5 Y1l & , $44155^{*}$ & 16234 & ,037 & 0188 & 8643 \\
\hline & & 11-15 Y1l &,- 13262 & 20926 & ,921 &,- 6776 & ,4123 \\
\hline & \multirow{3}{*}{ 11-15 Y1l } & 1 Yıldan Az & 13889 & 26554 & ,953 &,- 5526 & 8304 \\
\hline & & 1-5 Yil &, $57417^{*}$ & 19742 & ,022 & ,0601 & 1,0883 \\
\hline & & 6-10 Y 11 & ,13262 & ,20926 & ,921 &,- 4123 & ,6776 \\
\hline
\end{tabular}

Sonuç olarak, Tukey HSD testi kullanılarak yapılan post hoc karşılaştırmasında ortalama ve standart sapma değerleri ve önem düzeyleri göz 
önünde bulundurulduğunda, 11-15 yıl firmada çalışanların diğer gruplardan daha yüksek presenteizm algısına sahip oldukları, yine bu grubun çalışma süresi 1-5 yıl arası olan çalışanlardan daha yüksek psikolojik odaklı presenteizm algılarına sahip oldukları, ancak iş odaklı presenteizm algılarının farklılaşmadığı belirlenmiştir. İşletmede uzun süredir çalışanların, daha kısa süredir çalışanlara göre presenteizmi daha çok deneyimledikleri görülmektedir.

- Araştırma Sorusu 2: Çalışanların rol belirsizliği ve iş stresi yaşamaları ile presenteizmi algılamaları arasındaki ilişki var mıdır?

Rol belirsizliği ve iş stresinin presenteizm ve boyutları arasındaki ilişkileri incelemek amacıyla korelasyon analizi yapılmıştır (Bakınız Tablo 9). Parametrik veri seti özelliğinden dolayı Pearson korelasyonu tercih edilmiştir (Gürbüz ve Şahin, 2017). Analiz sonucunda presenteizm, iş odaklı presenteizm ve psikolojik odaklı presenteizm boyutları ile rol belirsizliği ve iş stresi arasında pozitif yönlü anlamlı bir ilişki olduğu tespit edilmiştir.

Tablo 9: Değişkenlere İlişkin Korelasyon Analizi Sonuçları

\begin{tabular}{|c|c|c|c|c|c|}
\hline Değişkenler & 1 & 2 & 3 & 4 & 5 \\
\hline Presenteizm & 1 & & & & \\
\hline $\begin{array}{l}\text { İş Odaklı } \\
\text { Presenteizm }\end{array}$ & $761^{* *}$ & 1 & & & \\
\hline Psikolojik Odaklı Presenteizm &, $767^{* *}$ & 168 & 1 & & \\
\hline Rol Belirsizliği &, $373^{* *}$ &, $256^{* *}$ &, $314^{* *}$ & 1 & \\
\hline İş Stresi & $399^{* *}$ & $207^{*}$ & , 402 & , $414^{* *}$ & 1 \\
\hline
\end{tabular}

- Araştırma Sorusu 3: Rol belirsizliği ve iş stresinin presenteizm üzerindeki etkisi nedir?

Rol belirsizliği ve iş stresinin presenteizm üzerindeki etkisinin incelenmesi için, regresyon analizi yapılmıştır. Bağımsız değişken sayısının birden fazla olması nedeniyle çoklu regresyon (multiple linear regression) modeli kullanılmış olup, az sayıda bağımsız değişken olduğu için "Enter" metodu seçilmiştir (Kalaycı, 2010, s.263). Yapılan çoklu regresyon analizlerine ait sonuçlar Tablo 10, Tablo 11 ve Tablo 12' de yer almaktadır. 
Tablo 10: Presenteizm Değişkenine İlişkin Çoklu Regresyon Analizi Sonuçları

\begin{tabular}{|c|c|c|c|c|c|c|c|c|c|}
\hline \multirow{5}{*}{$\begin{array}{l}\text { Mo- } \\
\text { del }\end{array}$} & \multirow[b]{2}{*}{$\begin{array}{l}\text { Bağımsız } \\
\text { Değişkenler }\end{array}$} & \multicolumn{7}{|c|}{ Bağımlı Değişken: Presenteizm } & \multirow[b]{2}{*}{$\begin{array}{l}\text { Durbin } \\
\text { Watson }\end{array}$} \\
\hline & & $\beta$ & $\mathbf{t}$ & \multirow[t]{2}{*}{ p } & $\mathbf{R}^{2}$ & $\begin{array}{l}\text { Düz. } \\
\mathbf{R}^{2}\end{array}$ & F & VIF & \\
\hline & Rol & & & & & & & & \\
\hline & Belirsizliği & ,250 & 2,868 & ,005 & & & & 1,207 & 1,907 \\
\hline & İş Stresi & ,295 & 3,383 & ,001 & 211 & 199 & 16,732 & 1,207 & \\
\hline
\end{tabular}

Analiz sonucuna göre presenteizmin \%21,1'inin bağımsız değişkenler olan iş stresi ve rol belirsizliği tarafından açıklandığı belirlenmiştir. Analizde Durbin Watson testi değerinin 1,907 olması otokorelasyonun diğer bir ifade ile bağımsız değişkenler arasında bağlantının olmadığını göstermektedir (Kalayc1, 2010: 263). F değeri ise modelin bir bütün olarak her düzeyde $(p=, 00)$ anlamlı olduğunu ifade etmektedir.

Tablo 11: İş Odaklı Presenteizm Değişkenine İlişkin Çoklu Regresyon Analizi Sonuçları

\begin{tabular}{|c|c|c|c|c|c|c|c|c|c|}
\hline \multirow{5}{*}{$\begin{array}{l}\text { Mo- } \\
\text { del }\end{array}$} & \multirow{2}{*}{$\begin{array}{l}\text { Bağımsız } \\
\text { Değişkenler }\end{array}$} & \multicolumn{8}{|c|}{ Bağımlı Değişken: İş Odaklı Presenteizm } \\
\hline & & $\beta$ & $t$ & p & $\mathbf{R}^{2}$ & $\begin{array}{l}\text { Düz. } \\
\mathbf{R}^{2}\end{array}$ & $\mathbf{F}$ & VIF & $\begin{array}{l}\text { Durbin } \\
\text { Watson }\end{array}$ \\
\hline & Rol & & & & & & & & \\
\hline & Belirsizliği & ,206 & 2,179 & 031 & & & & 1,207 & 1,844 \\
\hline & İş Stresi & 121 & 1,286 & 201 & 078 & ,063 & 5,268 & 1,207 & \\
\hline
\end{tabular}

Analiz sonucuna göre çalışanların presenteizmin bir boyutu olan iş odaklı presenteizme yönelik algısının \%7,8'inin bağımsız değişkenler olan İş Stresi ve rol belirsizliği tarafından açıklandığı belirlenmiştir. Analizde Durbin Watson testi değerinin 1,844 olması otokorelasyonun olmadığını; F değeri ise modelin bir bütün olarak ,01 güvenilirlik düzeyinde $(p=, 006)$ anlamlı olduğunu göstermektedir. Değişkenler içerisinde rol belirsizliği ,05 (p=,031) düzeyinde anlamlı çıkmıştır (Nakip, 2006, s. 338). İki bağımsız değişkenli çoklu regresyon analizinde bağımsız değişkenlerden birinin istatistiksel olarak anlamsız olmasına rağmen modelin bütünsel olarak anlamlı olması durumunda anlamsız çıkan değişkenin anlamlı çıkan bağımsız değişken ile bağımlı değişken arasında aracılık etkisi söz konusu olabilir (Koç, Kaya, Özbek ve Akkılıç, 2014, s. 6). İş stresi değişkeninin anlamlı çıkmamasına rağmen modelin ve rol belirsizliği değişkeninin anlamlı çıkması iş stresinin aracılık rolünün olabileceğini göstermektedir. 
Tablo 12: Psikolojik Odaklı Presenteizm Değişkenine İlişkin Çoklu Regresyon Analizi Sonuçları

\begin{tabular}{llllllllll}
\hline & Bağımsız & \multicolumn{8}{c}{ Bağımlı Değişken: Psikolojik Odaklı Presenteizm } \\
Mo- & $\begin{array}{l}\text { Değişkenler } \\
\text { del }\end{array}$ & $\boldsymbol{\beta}$ & $\mathbf{t}$ & $\mathbf{p}$ & $\mathbf{R}^{2}$ & $\begin{array}{l}\text { Düz. } \\
\mathbf{R}^{2}\end{array}$ & $\mathbf{F}$ & VIF & Watson \\
\cline { 2 - 10 } & Rol & & & & & & & 1,207 & 1,605 \\
& $\begin{array}{l}\text { Belirsizliği } \\
\text { İş Stresi }\end{array}$ &, 177 & 2,000 &, 048 & & & & 1,207 & \\
\hline
\end{tabular}

Analiz sonucuna göre çalışanların presenteizmin diğer boyutu olan psikolojik odaklı presenteizme yönelik algısının \%18,8'inin araştırmanın bağımsız değişkenleri olan iş stresi ve rol belirsizliği oluşturmaktadır. Analizde Durbin Watson testi değerinin 1,605 olması sebebiyle bağımsız değişkenler arasında otokorelasyonun olmadığı belirlenmiştir. F değeri incelendiğinde ise bir bütün olarak modelin her $(p=, 000)$ düzeyde anlamlı olduğu görülmüştür.

\section{Sonuç ve Öneriler}

Presenteizm, çalışanların fiziksel veya ruhsal rahatsızlıklar yaşamaları halinde işe gitmemeleri gerekirken mevcut işlerini kaybetme veya kariyerlerindeki hedeflerine ulaşamama korkusu gibi sebeplerden ötürü işe gitmeleri durumu olarak tanımlanmaktadır (Lowe, 2002). Bu durumda çalışmaya devam edilmesi bireyin hata yapmasına, düşük performans ve verimliliğe, uzun vadede tükenmişlik ve depresyona neden olmaktadır (Burton vd., 2006). Bu araştırmanın amacı hem örgüt hem de çalışan verimliliği ve sürekliliği açısından önem taşıyan presenteizmin iş stresi ve rol belirsizliği ile arasındaki ilişkilerin açıklanmasıdır. İlişkiyi incelemek amacıyla üç araştırma sorusu geliştirilmiş ve analizler ile bulgular incelenmiştir.

Araştırma sorularının incelenmesinde bağımsız örneklem $t$ testi, ANOVA, korelasyon analizi ve çoklu regresyon analizleri kullanılmıştır. İlk araştırma sorusu, çalışanların presenteizm algılarının değerlendirilmesine yönelik olup, cinsiyet, eğitim düzeyi ve iş yerindeki kıdemine göre farklılaşması incelenmiştir. Analiz sonucunda, presenteizmin üç türünün de cinsiyete göre farklılaşmadığı, presenteizm algısının ortalamalarının 
birbirine yakın olduğu belirlenmiştir. Seçilen örneklemdeki kadın sayıs1nın az olması bu durumu etkileyen bir etken olabileceği gibi bu sonuç genelleştirilememektedir. Presenteizm ile cinsiyet arasında ilişki arayan önceki araştırmalarda genelde kadınların erkeklerden daha fazla presenteizm yaşadıkları sonucuna varılmıştır (Örücü ve Kaplan, 2011; Aronsson vd., 2000, s.505). Ancak, farklılaşmanın olmadığı sonucuna varan araştırmalarda bulunmaktadır (Bölür, 2018, s. 217).

Katılımcıların presenteizm algılarının sahip oldukları eğitime göre farklılaşmasını incelemek amacıyla Tek yönlü ANOVA analizi yapılmıştır. Yapılan analiz sonucunda psikolojik odaklı presenteizm boyutu aç1sından eğitim düzeyi grupları arasında anlamlı bir fark görülmezken presenteizm boyutlarından iş odaklı presenteizm boyutu ve presenteizm tek boyutlu değerlendirildiği durumda çalışanların eğitim düzeyleri arasında anlamlı bir farklılık belirlenmiş olup, lisans ve yüksekokul eğitimine sahip çalışanların presenteizmi diğer eğitim gruplarındaki çalışanlardan daha yüksek algıladıkları belirlenmiştir.

Çalışanların presenteizm algılarının firmada çalışma sürelerine göre farklılaşmasını incelemek amacıyla Tek yönlü ANOVA analizi yapılmıştır. Yapılan analiz sonucunda, presenteizm ve alt boyutu olan psikolojik odaklı presenteizm algılarının iş yerinde çalışma süresine göre farklılaştığı, ancak iş odaklı presenteizm algılarının farklılaşmadığı görülmektedir. İşletmede uzun süredir çalışanların, daha kısa süredir çalışanlara göre presenteizmi daha çok deneyimledikleri belirlenmiştir. İş yerinde çalışma süresinin artması örgüte bağlılığı arttırırken yaşın da ilerlemiş olmasının getirdiği rahatsızlıkların fazlalaşması sebebiyle presenteizmde artış görülebilmektedir (Koçoğlu, 2007; Örücü ve Kaplan, 2001).

İkinci araştırma sorusu rol belirsizliği ve iş stresinin presenteizm ve alt boyutları ile ilişkisine yöneliktir. İlişkileri incelemek amacıyla korelasyon analizi yapılmıştır. Analizler sonucunda, presenteizm ve alt boyutları olan iş odaklı presenteizm ve psikolojik odaklı presenteizmin iş stresi ve rol belirsizliği ile arasında pozitif yönlü anlamlı bir ilişki bulunmuştur.

Üçüncü araştırma sorusu ise rol belirsizliği ve iş stresinin presenteizm üzerindeki etkisini araştırmaya yönelik olup, incelemek amacıyla çoklu regresyon analizinden faydalanılmıştır. Analizler sonucunda presenteizmin tek boyut olarak değerlendirildiğinde \%21,1'inin, iki boyut olarak de- 
ğerlendirildiğinde ise psikolojik odaklı presenteizmin \%18,8'inin araştırmanın bağımsız değişkenleri olan iş stresi ve rol belirsizliği tarafından meydana geldiği belirlenmiştir. İş stresi ve rol belirsizliği değişkenlerinin iş odaklı presenteizmin üzerindeki etkisi incelediğinde ise rol belirsizliğinin iş odaklı presenteizm üzerinde anlamlı bir etkisi olduğu, iş stresinin iş odaklı presenteizm üzerinde anlamlı bir etkisinin olmadı̆̆ tespit edilmiştir. Ancak modelin bütünü istatistiksel olarak anlamlı olup, \%7,8'inin bu değişkenler tarafından oluştuğunu göstermektedir. İş stresi değişkeninin anlamlı çıkmamasına rağmen modelin ve rol belirsizliği değişkeninin anlamlı çıkması iş stresinin aracılık etkisinin olabileceğini göstermektedir. Nitekim korelasyon analizi sonuçları iş stresinin her iki değişkenle arasında anlamlı ilişkilerin olması aracılık etkisi olabileceğini destekler niteliktedir. İşs stresinin aracılık etkisi başka bir araştırmanın konusu olup, incelenmesi presenteizmi etkileyen faktörlerin açklanması konusunda katkı sağlayacaktır.

Sonuçlar incelendiğinde düşük düzeyde ve anlamlı etkiler olduğu görülmektedir. Presenteizm ve alt boyutlarını etkileyebilecek değişken sayısının yüksek olması nedeniyle iş stresi ve rol belirsizliğinin etki seviyelerinin düşük kalmış olması mümkündür. Ayrıca, araştırmaya katılan mavi yakalı çalışan sayısının yüksekliği ve fiziksel emek yoğun bir sektör olması sebebiyle iş odaklı presenteizm üzerinde rol belirsizliği ve iş stresinin rolünün düşük olduğu düşünülmektedir. Rol belirsizliği ve iş stresinin çalışanlar üzerinde depresyon, tükenmişlik gibi olumsuz sorunlara yol açması (Baklacı, 2013, s.14) ve bu durumda çalışmalarının presenteizme sebep olması (Arslaner ve Boylu, 2015, s.128) sebebiyle psikolojik odaklı presenteizm üzerinde nispeten daha yüksek orana sahip olduğu düşünülmektedir.

Araştırmada elde edilen bulgular sonucunda iş stresinin ve rol belirsizliğinin presenteizm ve alt boyutları olan psikolojik odaklı presenteizm ve iş odaklı presenteizm arasındaki ilişkiler ortaya konulmuştur. Bu bağlamda presenteizmin önlenebilmesi amaciyla etkileyen faktörlere yönelik araştırmaların arttırılması fayda sağlayacaktır. Uygulamacılar açısından özellikle yöneticilerin presenteizmin sonuçları ve etkileyen faktörlere ilişkin bilgilendirilmesi, engelleyici önlemler alması gerekmektedir. Örgüt içerisinde iş stresini oluşturan faktörler belirlenerek minimize edilmeli ve 
çalışanlar stres yönetimine yönelik eğitimler ile desteklenmelidir. Yöneticilerin kurum içerisinde destekleyici örgüt kültürü oluşturulmalı, çalışanın özlük haklarının güvencesinin verilmesi ve güven ortamı sağlanmalıdır. İş analizleri ve iş tanımları yapılarak rol belirsizliğinin önüne geçilmelidir. Araştırmalar sonucunda çalışanların görevlerinin içeriği ve süreçleri üzerine kontrol sahibi olmalarının rol belirsizliğini azalttığı görülmüştür (Sang-Hoon, Yuhyung ve Seung, 2017). Çalışanların görevlerine ilişkin süreçlerde özerklik veya katılımlarının sağlanması ile rol belirsizliğinin dolayısı ile presenteismin azaltılması sağlanabilir.

Tek bir firmadan veri toplanması, mavi yakalı çalışanların yoğunlukta olması araştırmanın kısıtlarını oluşturmaktadır. Araştırma kısıtlarına rağmen, presenteizm kavramının açılanması, iş stresi ve rol belirsizliği arasındaki ilişkileri ortaya koyarak yazına ve söz konusu ilişkilerin çalışma yaşamında değerlendirilerek önlemler alınması ile uygulamaya katkı sağlanması beklenmektedir. Gelecekte yapılacak olan araştırmalarda örneklem sayısının arttırılması, farklı sektörlerde test edilmesinin hem ölçeğin güvenilirlik ve geçerliliği bakımından hem de presenteizm ile ilişkili diğer kavramların incelenerek değerlendirilmesi bakımından uygulamacılara ve yönetim ve organizasyon yazınına katkı sağlayacağı beklenmektedir. 


\title{
EXTENDED ABSTRACT
}

\section{Determination The Effect of Work Stress and Role Ambiguity on Presenteeism}

\author{
Meryem Derya Yeşiltaş - Esra Ayaz \\ * \\ Osmaniye Korkut Ata Üniversitesi
}

Presenteeism, is the situation which employee goes to work despite the discomfort and to existence physically at work but not mentally (Lowe, 2002). Presenteeism causes work-related mental and physical illnesses such as long-term illness, anxiety, stress, injury, depression, headache and back pain, early retirement, also it may cause some problems such as alcohol and drug addiction and imbalances in work-family life (Hemp, 2004; Quazi, 2013).

Presenteeism, which causes various problems and big costs in working life, is a situation that occurs especially in employees with heavy workloads and responsibilities. Presenteeism is seen more frequently due to the inconveniences in the workers with heavy workload and responsibility and it is more common in enterprises which has intensive stress factor (Koçoğlu, 2007). While stress directly affects employees, it determines their behavior, productivity and relationships with other employees. It was determined that role ambiguity and work stress had negative consequences such as physical and mental disorders, inability to work, lack of self-confidence, job dissatisfaction, and decrease in quality of decisions and creativity (Bartram et al., 2004). As a matter of fact, it was seen that the incapacity rates of the employees who had experienced role ambiguity and intense stress were higher. When employees are mentally or physically uncomfortable, even if they become intermittently inoperable for a while, they may not want to go to work. Due to the necessity to go to work, the employee has low performance and faulty work so it will cause a decrease in productivity in general (Yeşiltaş and Erbaş, 2017). 
The aim of this study is to examine presenteeism perceptions of employees, to explain how work stress and role ambiguity affect presenteeism and to evaluate them at sub-dimensions (work focus presenteeism and psychological focus presenteeism).

1) Do presenteeism perceptions of employees differ according to demographic variables?

2) Is there a relationship between employee ambiguity and work stress and presenteeism?

3) What is the effect of role ambiguity and work stress on presenteeism?

The population of the study consists of a total of 133 people who work in furniture factory in Kahraman Maraş Organized Industrial Zone. The number of questionnaires collected was 130 . The number of valid questionnaires, which were used in analysis, was 128 . The applied questionnaire rate was $97,74 \%$.

The first research question was aimed at evaluating employees' perceptions of presenteeism and examined the differentiation according to gender, education level and seniority in the workplace. As a result of the analysis, it was determined that all three types of presenteeism did not differ according to gender and the mean of presenteeism perception was close to each other. One-way ANOVA analysis was conducted in order to examine the differentiation of presenteeism perceptions of the participants according to their education. As a result of the analysis, no significant difference was observed between the education level groups in terms of psychological focus presenteeism dimension whereas a significant difference was found between the education levels of the employees in both one-dimension presenteeism and its work focus subdimension. it was found that employees with undergraduate and higher education perceived presenteeism higher than those in other education groups.

One-way ANOVA analysis was performed in order to examine the differences in employees' perceptions of presenteeism according to their seniority in the organization. As a result of the analysis, it is seen that psychological focus presenteeism perceptions, which is one of subdimension of presenteeism, differ according to the seniority in the workplace but 
work focus presenteeism perceptions do not. It has been determined that long-term employees experience presenteeism more than short-term employees. The seniority in the workplace increases the commitment to the organization, but also increases in presenteeism due to the enhance of discomfort caused by the advanced age (Koçoğlu, 2007; Örücü and Kaplan, 2001).

The second research question focuses on the relationship between role ambiguity and work stress with presenteeism and its subdimensions. Correlation analysis was performed to investigate the relationships. As a result of the analyzes, a significant positive relationship was found between presenteeism (also with its subdimensions work focus presenteeism and psychological focus presenteeism) and work stress and role ambiguity.

The third research question was aimed to investigate the effect of role ambiguity and work stress on presenteeism and multiple regression analysis was used to investigate. As a result of the analysis, it was determined as a one dimension that $21.1 \%$ of presenteeism was caused by work stress and role ambiguity which are independent variables of research. When it was examined as two dimension, the rate was found $18.8 \%$ of psychologically focus presenteeism. When the effects of work stress and role ambiguity variables on work focus presenteeism were examined, it was found that role ambiguity had a significant effect on work focus presenteeism. On the other hand, it was found that work stress did not have a significant effect on work-focus presenteeism. However, the whole model is statistically significant and shows that $7.8 \%$ of work focus presenteeism dimension is formed by the independent variables. Although work stress variable did not appear to be significant, the model and role ambiguity variables were significant and it showed that work stress might have mediating effect. As a matter of fact, the results of correlation analysis support that there is a significant relationship in terms of mediating effect between work stress and both variables. The mediating effect of work stress is the subject of another study and its analysis will contribute to the explanation of the factors which effect presenteeism.

As a result of the findings obtained in the study, the relationships between presenteeism and its sub-dimensions (psychological-focus presenteeism and work-focus presenteeism), were revealed. In this context, it will be beneficial to increase the researches about the factors affecting the 
presenteeism in order to prevail of presenteeism. In terms of practitioners, especially managers should be informed about the results of presenteeism and the factors that affect it, and preventive precautions should be taken. Factors that constitute work stress within the organization should be identified and minimized. The employees should be supported with stress management trainings. Managers should create a supportive organizational culture, assure the employee's personal rights and provide an atmosphere of trust. Role ambiguity should be avoided by making job analyzes and job descriptions. As a result of the research, it was seen that having control over the content and processes of the tasks reduces the role ambiguity. By providing employees' autonomy or participation in the processes, the role ambiguity can be decreased. Hence, the presenteeism can be reduced due to decrease of the role ambiguity.

\section{Kaynakça / References}

Akdaş, E. (2015). Hemşirelerde rol çatışması ve rol belirsizliğinin tükenmişlik ve iş doyumuna etkisi:İstanbul Bayrampaşa Devlet Hastanesi ve İstanbul Avicenna Hospital Özel Hastanesi karşılaştırmalı örneği. Yayınlanmamış Yüksek Lisans Tezi, Beykent Üniversitesi Sosyal Bilimler Enstitüsü İşletme Yönetimi Anabilim Dalı Hastane ve Sağlık Kurumları Yönetimi Bilim Dalı, İstanbul.

Anık, B. İ., Baysal, G., Aksu, G., ve Aksu, N. (2014). Presenteeism (işte varolmama sorunu) ile örgütsel bağlılık arasındaki ilişki: Adnan Menderes Üniversitesi akademik personeli üzerinde bir uygulama. Electronic Journal of Vocational Colleges, BÜROKON Özel Say1s1, 134-152.

Aronsson, G., Klas, G. ve Margareta, D. (2000). Sick but yet at work. An empirical study of sickness presenteeism. Journal Epidemiology Community Health, 54 (7), 502-509.

Arslaner, E. ve Boylu, Y. (2015). İş hayatında presenteeism: Otel işletmeleri açısından bir değerlendirme, İşletme Araştırmaları Dergisi, 7(4),123-136. 
Bakan, İ., Doğan, İ. F., Yılmaz, S. Y., Oğuz, M. (2018). Sağlık Personellerinde presenteism algısının stres ve performans üzerindeki etkisi: Bir alan araştırması, The Journal of Academic Social Science Studies, 66(2), 373-386.

Baklacı, E. (2013). İş stresi ve tükenmişlik arasındaki ilişki: Banka çalışanları üzerinde bir araştırma. Yayınlanmamış Yüksek Lisans Tezi, Mustafa Kemal Üniversitesi, Sosyal Bilimler Enstitüsü, , Hatay.

Bal, F. (2014). Presenteizm ve psikolojik sözleşmenin duygusal zekâ ile ilişkisi: Gaziantep Üniversitesi'nde bir uygulama. Yayınlanmamış Yüksek Lisans Tezi, Gaziantep Üniversitesi Sosyal Bilimler Enstitüsü İşletme Anabilim Dalı, Gaziantep.

Balcı, O. (2016). Illköğretim okullarında görev yapan öğretmenler ve yöneticilerin örgütsel sinizm, kendini işe verememe (Presenteizm) ve sosyal kaytarma arasındaki ilişkinin incelenmesi:Arnavutköy İlçesi örneği, Yayınlanmamış Doktora Tezi, İstanbul Arel Üniversitesi Sosyal Bilimler Enstitüsü İşletme Yönetimi Anabilim Dalı, İstanbul.

Bartram, J, Joiner, T.A, Stanton, P. (2004). Factors affecting the job stres of Australian nurses: Implications for recruitment and retention, Contemporary Nurse, 17(3), 293-304.

Basım, N. H., Erkenekli, M. ve Şeşen, H. (2010). Birey davranışındaki kontrol odağının rol çatışması ve rol belirsizliği algısı ile ilişkisi: Kamu sektöründe bir araştırma. Amme İdaresi Dergisi, 43(1), 145165.

Beehr, T. A., ve Newman, J. E. (1978). Job stress, employee health, and organizational newman, John E.: Effectiveness: A facet analysis, model, and literature review, Personnel Psychology, 31, 665-699.

Bierla, I., Huver, B., ve Richard, S. (2013). New evidence on absenteeism and presenteeism, The International Journal of Human Resource Management, 24(7), 1536-1550.

Biron, C., Brun, J., Ivers, H., ve Cooper, C. L. (2006). At work but ill: Psychosocial work environment and well-being determinants of presenteeism propensity, Journal of Public Mental Health, 5(4), 26-37.

Bölür, S. (2018). Algılanan liderlik davranışının örgütsel sinizm ve presenteizm üzerine etkisini belirlemeye yönelik bir araştırma. Yayınlanmamış Yüksek Lisans Tezi Trakya Üniversitesi Sosyal Bilimler Enstitüsü İşletme Anabilim Dalı, , Edirne. 
Burton, W, N., Chen, C. Y, Cont1, D. J., Schultz, A. B., ve Edıngton, D. W. (2006). The association between health risk change and presenteizm change, Journal of Occupational and Environmental Medicine, 48(3), 252-263.

Ceylan, A. ve Ulutürk, Y. H. (2006). Rol belirsizliği, rol çatışması, iş tatmini ve performans arasındaki ilişkiler, Doğuş Üniversitesi Dergisi, 7(1), 48-58.

Çelik, M. ve Turunç, Ö. (2009). Aile-iş çatışması, iş stresi ve örgütsel sadakatin iş performansına etkisi: Savunma sektöründe ampirik bir çalışma, Savunma Bilimleri Dergisi, 8(2), 217-245.

Chia, Y.M. ve Chu, M.J.T. (2016). Moderating effects of presenteeism on the stress-happinessrelationship of hotel employees: A note. International Journal of Hospitality Management, 55, 52-56.

Çiftçi, B. (2010). İşte var ol(ama)ma sorunu ve işletmelerin uygulayabileceği çözüm önerileri, Çalışma ve Toplum, 1, 155.

Cooper, C.L. (1998). The changing nature of work. Community Work and Family, 1(3),313-317.

Deery, M. ve Jago, L. (2009). A framework for work - life balance practices: Addressing the needs of the tourism industry, Tourism and Hospitality Research , 2(9), 106.

Efeoğlu, E. ve Özgen, H. (2007). İş-aile yaşam çatışmasının iş stresi, iş doyumu ve örgütsel bağlllık üzerindeki etkileri: İlaç sektöründe bir araştırma, Çukurova Üniversitesi Sosyal Bilimler Enstitüsü Dergisi, 16(2), 237-354.

Erbaş, K. (2017). Presenteizm ile duygusal bağlllık arasındaki ilişki: seyahat acentaları üzerine bir uygulama, Yüksek Lisans Tezi, Gazi Üniversitesi Sosyal Bilimler Enstitüsü, Turizm İşletmeciliği Anabilim Dalı, Ankara.

Eroğlu, F. (2007). Davranış bilimleri. (8. Basım), İstanbul: Beta Basım AŞ.

Gilbreath, B. ve Karimi, L. (2012). Supervisor behavior and employee Presenteeism, International Journal of Leadership Studies, 7(1), 114-131.

Gürbüz, S. ve Şahin, F. (2017). Sosyal bilimlerde araştırma yöntemleri. (4. Bask1), Ankara: Seçkin Yayıncılık.

Hair J.F, Anderson, R.E., Tatham, R. L, ve Balck, W.C. (1995). Multivariate data analysis with readings. (4. Bask1), New Jersey: Prentice Hall. 
Hansen, C. D. ve Andersen, J.H. (2008). Going ill to work- what personal circumstances, attitudes and work-related factors are associated with sickness presenteeism, Social Science and Medicine, 67(6), 956964.

Hemp, P. (2004). Presenteeism: At work-but out of it. Harvard Business Review, 82(10),49-58.

Johns, G. (2010). Presenteeizm in the workplace: A review and research agenda, Journal of Organizational Behavior, 31, 519-542.

Kalaycı, Ş. (2010). SPSS uygulamal çok değişkenli istatistik teknikleri, (5. Baskı), Ankara: Asil Yayın Dağıtım.

Kara, H. ve Sezici, E. (2013). Girişimci kadın yöneticilerin stres altında kendini denetleme becerileri: $\mathrm{Bu}$ konuda düzenlenen bir anket çalışmasının sonuçları, The Journal of Academic Social Science Studies, 6(2), 669-695.

Kaygın, E., Kerse, G. ve Yılmaz, T. (2017). Kamu çalışanlarında örgütsel bağlllık ve presenteeism arasındaki ilişki: Kars İl örneği. Ombudsman Akademik, 6, 181-204.

Koçoğlu, M. (2007). İşletmelerde presenteeism sorunu ve insan kaynakları yönetimi çerçevesinde mücadele yöntemleri, Yayınlanmamış Yüksek Lisans Tezi, Yıldız Teknik Üniversitesi Sosyal Bilimler Enstitüsü, İstanbul.

Koç, F., Kaya, N., Özbek, V., ve Akkılıç, M.E. (2014). algılanan fiyat ile tüketici güveni arasında algılanan hizmet kalitesinin aracı etkisi: bankacılık ve gsm sektörlerinin karşılaştırılmasına yönelik bir araştırma, Pazarlama ve Pazarlama Araştırmaları Dergisi, 13, 1-26.

Koopman, C., Pelletier, K. R., Murray, J. F., Sharda, C. E., Berger, M. L., Turpın, R. S., Hackleman, P., Gibson, P., Holmes, D. M., Bendel, T. (2002). Stanford presenteeism scale: Health status and employee productivity, Journal of Occupational Environmental Medicine, 44(1), 14-20.

Lowe, G. (2002). Here in body, Absent in productivity. hr reporter, The National Journal Of Human Resource Management, 1-2.

Macgregor, J.N., Cunningham, J.B. ve Caverley, N. (2008). Factors in absenteeism and presenteeism: Life events and health events, Management Research News, 31(8), 607-615. 
Nakip, M. (2006). Pazarlama araştırmaları teknikler ve (SPSS destekli) uygulamalar. (1. Bask1), Ankara: Seçkin Yayıncilık.

Oruç, Ş. (2015). Presenteizm ile örgütsel sessizlik arasındaki ilişki üzerine bir araştırma, Yayınlanmamış Yüksek Lisans Tezi, Aksaray Üniversitesi Sosyal Bilimleri Enstitüsü İşletme Anabilim Dalı, Aksaray.

Örücü, E. ve Kaplan, E. (2001). Kamu ve özel sektör çalışanlarında devamsızlık sorunu, Celal Bayar Üniversitesi İktisadi ve İdari Bilimler Fakültesi, Yönetim ve Ekonomi Dergisi, 7(1), 93-112.

Özmen, G. (2011). Presenteizm ile örgütsel bağhllık ilişkisi: Tekstil çalışanları üzerinde bir araştırma, Yayınlanmamış Yüksek Lisans Tezi, Eskişehir Osmangazi Üniversitesi Sosyal Bilimler Enstitüsü, İşletme Anabilim Dall, Eskişehir.

Quazi, H. (2013). Presenteeism: The invisible cost to organizations. Hampshire: Palgrave Macmillan. 22.02.2019 tarihinde http://www.palgrave.com/page/detail/presenteizm-hesan-quazi/adresinden erişilmiştir.

Robertson, I. ve Cooper, C. L. (2011). Well-being: Productivity and happiness at work. (1. Bask1). Hampshire: Palgrave Macmillan.

Roelen, C. A., ve Groothoff, J. W. (2013). Rigorous management of sickness absence provokes sickness presenteeism. Occupational Medicine, 60(4), 244-245.

Sang-Hoon, L., Yuhyung, S. ve Seung, I.B. (2017). Task characteristics andwork engagement: Exploring effects of role ambiguity and 1ct presenteeism, Sustainability, 9, 1855. doi:10.3390/su9101855.

Sager, J. K. (1994). A Structural Model depicting salespeople's job stress, Journal of the Academy of Marketing Science, 22(1), 74-84.

Schafer, W. (1987). Stress management for wellness. New York: Mc Graw Hill Şimşek, Ş., Akgemci, T., Çelik, A. (2010). Davranış Bilimlerine Giriş ve Örgütlerde Davranış, Ankara: Nobel Yayın Dağıtım.

Tunç, T. (2008). Doktor ve hemşirelerde tükenmişlik ile rol çatışması ve rol belirsizliği arasındaki ilişki: Bir üniversite hastanesi örneği, Yayınlanmamış Yüksek Lisans Tezi,, Sakarya Üniversitesi Sosyal Bilimler Enstitüsü, Sakarya.

Turunç, Ö. ve Çelik, M. (2010). Çalışanların algıladıkları örgütsel destek ve iş stresinin örgütsel özdeşleşme ve iş performansına etkisi. Ÿ̈netim ve Ekonomi, 17(2), 183-206. 
Yang, T., Yina, G., Mingxu, M., Yaxin, L., Hullin, T. ve Jianwei, D. (2017). Job stress and presenteeism amongchinese healthcare workers: The mediating effects of affective commitment, Int. J. Environ. Res. Public Health, 14, 978. doi:10.3390/ijerph14090978.

Yeşiltaş, M. D. ve Türk, M. (2017). İş stresinin çalışanların iş akış deneyimleri üzerindeki etkisi, Uluslararası Sosyal Araştırmalar Dergisi, 10(54), 935-941.

Yeşiltaş, M. ve Erbaş, E. (2017). Presenteizm ile duygusal bağlılık arasındaki ilişki: seyahat acentaları üzerine bir uygulama, Çukurova Üniversitesi IIBFF Dergisi, 21(1), 121-135.

Yurdadön, C. (2018). Psikolojik sermaye ile iş stresi ilişkisi: TCDD makinistleri üzerine bir araştırma. Yayınlanmamış Yüksek Lisans Tezi, Türk Hava Kurumu Üniversitesi, Sosyal Bilimler Enstitüsü, Ankara.

Webster, J.R., Beehr, T.A. ve Love, K. (2011). Extending the challengehindrance model of occupational stress: The role of appraisal, Journal of Vocational Behaviour, 79, 505-506.

Zhou, Q., Martinez, L. F., Ferreira, A. I. ve Rodrigues, P. (2016) Supervisor support, role ambiguity and productivity associated with presenteeism: a longitudinal study, Journal of Business Research, 69 (9). 3380-3387.

\section{Kaynakça Bilgisi / Citation Information}

Yeşiltaş, D., M. ve Ayaz, E. (2019). İş stresi ve rol belirsizliğinin presenteizm (işte var olamama) üzerindeki etkisinin belirlenmesi OPUSUluslararası Toplum Araştırmaları Dergisi, 12(18. UíK Özel Sayısı), 741-771. DOI: 10.26466/opus.601608 